\title{
Efek Pemberian Ekstrak Jahe (Zingiber officinale) terhadap Gambaran Histopatologik Lambung Tikus Wistar yang Diinduksi Asam Asetat
}

\author{
Monica Ch. Pungus, ${ }^{1}$ Magdalena P. Lintong, ${ }^{2}$ Maria K. Sambuaga ${ }^{2}$
}

\author{
${ }^{1}$ Program Studi Pendidikan Dokter Fakultas Kedokteran Universitas Sam Ratulangi Manado \\ ${ }^{2}$ Bagian Patologi Anatomi Fakultas Kedokteran Universitas Sam Ratulangi Manado \\ Email: monicachpungus@gmail.com
}

\begin{abstract}
In stomach induced by acetic acid, the gastric acidity may increase leading to irritation of the mucosal layer and imbalance of defense factors and damaging factors. This might lead to the occurrence of gastritis or peptic ulcers. Ginger is rich in flavonoids. In the inflammation process, ginger constituents such as zingerone, zingiberenes, gingerols, and shogaol may be able to inhibit the cyclooxygenation and lipookoxygenase pathways in the arachidonic acid metabolism. This study was aimed to identify the effects of ginger on the histopathological features of stomach induced by acetic acid. This was an experimental laboratory study. In this study, we used red ginger (Zingiber officinale var. rubrum) originated from Tomohon. Samples were male Wistar rats (Rattus norvegicus) divided into 5 groups; one as the positive control. The results showed that groups given ginger had intact surface mucosa, inflammation cells (eosinophils and PMN), and blood vessel dilation. Meanwhile, the positive control showed erosive surface mucosa. Worms were identified in all groups. It is concluded that in Wistar rats, administration of ginger after the stomach induced by acetic acid still showed gastritis feature but without acute erosive gastritis.
\end{abstract}

Keywords: ginger, stomach, gastritis, peptic ulcers, acetic acid, vinegar

\begin{abstract}
Abstrak: Pada lambung yang diinduksi dengan asam asetat, kadar keasaman lambung dapat meningkat sehingga mengiritasi lapisan mukosa dan mengakibatkan ketidakseimbangan faktor pertahanan dan faktor perusak lambung. Hal ini dapat menyebabkan gastritis atau ulkus peptikum. Jahe dikenal kaya akan flavonoid. Pada proses inflamasi, konstituen dari jahe seperti zingerone, zingiberenes, gingerols, dan shogaol mampu menghambat jalur siklooksigenasi dan lipooksigenase pada metabolisme asam arakidonat. Penelitian ini bertujuan untuk mengetahui efek pemberian jahe terhadap gambaran histopatologik lambung yang diinduksi dengan asam asetat. Jenis penelitian ialah eksperimental laboratorik. Pada penelitian ini digunakan jahe merah (Zingiber officinale var. rubrum) yang berasal dari daerah Tomohon. Sampel penelitian ialah 25 ekor tikus Wistar (Rattus norvegicus) jantan, dibagi atas 5 kelompok; satu kelompok sebagai kontrol positif. Hasil penelitian mendapatkan kelompok yang diberikan jahe memperlihatkan permukaan mukosa lambung intak, adanya sel-sel radang (eosinofil dan PMN), serta pelebaran pembuluh darah sedangkan pada kelompok kontrol positif yang hanya diberikan asam asetat tampak permukaan mukosa lambung erosif. Pada semua sampel ditemukan adanya cacing. Simpulan penelitian ini ialah pada tikus Wistar, pemberian jahe setelah lambung diinduksi dengan asam asetat masih menunjukkan adanya gambaran histopatologik gastritis namun tidak terdapat gastritis erosif akut.
\end{abstract}

Kata kunci: jahe, lambung, gastritis, ulkus peptikum, asam asetat

\section{PENDAHULUAN}

Jahe adalah tumbuhan aromatis dengan rimpang bercabang simpodial, batang semu dengan tinggi sekitar $1 \mathrm{~m}$ dan kaya akan flavonoid. ${ }^{1}$ Secara umum jahe digunakan sebagai obat tradisional untuk mengobati mabuk perjalanan, mual, muntah, diare, batuk, nyeri otot, demam, migraine dan perdarahan. Namun dalam penelitian beberapa tahun terakhir, telah ditemukan bahwa 
jahe memiliki aktivitas biologik yang dapat digunakan sebagai antiulkus, antioksidan, dan antiinflamasi. ${ }^{2-8}$ Efek farmakologik dari jahe disebabkan oleh konstituen yang terdapat dalam jahe di antaranya zingerone, zingiberenes, gingerols, dan shogaol sebagai komponen bioaktif fenolik utama yang dapat menghambat inflamasi, angiogenesis, proliferasi, reactive oxygen species (ROS), dan meningkatkan produksi sel mast. $^{4,9-12}$

Gastritis dan ulkus peptikum merupakan lesi yang terdapat pada mukosa lambung. Lesi ini disebabkan oleh ketidaksetimbangan antara agen perusak (damaging forces) dan faktor pelindung (defensive forces) sehingga menyebabkan iritasi pada permukaan mukosa bahkan dapat mencapai submukosa, muskularis propia, atau lapisan yang lebih dalam lagi. ${ }^{13}$

Asam asetat yang dikenal dengan cuka merupakan asam organik larut air yang sering digunakan sebagai bahan penyedap makanan. Asam asetat dapat menyebabkan cedera pada organ maupun jaringan karena sifatnya yang korosif dan iritan. ${ }^{14}$ Pada lambung, asam asetat dapat meningkatkan agen perusak dan mengakibatkan ketidakseimbangan bagi lambung dan menyebabkan gastritis atau ulkus peptikum. Jahe telah diteliti memiliki kandungan yang dapat berperan sebagai anti-inflamasi serta antiulkus sehingga memungkinkan untuk terjadinya perbaikan pada jaringan yang mengalami gastritis atau ulkus peptikum.

Berdasarkan latar belakang ini maka penulis ingin mengetahui gambaran mikroskopik lambung yang telah diinduksi oleh asam asetat yang kemudian diberikan jahe pada tikus Wistar jantan.

\section{METODE PENELITIAN}

Penelitian ini dilakukan di Laboratorium Patologi Anatomi Fakultas Kedokteran Universitas Sam Ratulangi Manado. Jenis penelitian ialah eksperimental laboratorik dengan randomized post-test only control group design.

Sampel penelitian ialah 25 ekor tikus Wistar jantan dengan berat rerata 200gr yang telah dilakukan penyesuaian selama 2 minggu. Pada penelitian ini digunakan jahe merah (Zingiber officinale var. rubrum) yang berasal dari daerah Tomohon (Gambar 1) dan asam asetat yang digunakan yaitu cuka dapur dengan konsentrasi $5 \%$.

Sampel penelitian dibagi atas 5 kelompok yaitu kelompok I, II, III, IV, dan V. Kelompok I diberi asam asetat 5\% 0,5 ml selama 3 hari dan diterminasi pada hari ke4. Kelompok II diberikan asam asetat 5\% $0,5 \mathrm{ml}$ dan ekstrak jahe $0,51 \mathrm{mg} / \mathrm{ml}$ secara bersamaan selama 13 hari dan diterminasi pada hari ke-14. Kelompok III diberikan asam asetat 5\% $0,5 \mathrm{ml}$ selama 3 hari dilanjutkan dengan ekstrak jahe $0,51 \mathrm{mg} / \mathrm{ml}$ selama 10 hari, kemudian diterminasi pada hari ke-14. Kelompok IV diberikan asam asetat 5\% 0,5 ml selama 3 hari dilanjutkan dengan ekstrak jahe $1,02 \mathrm{mg} / \mathrm{ml}$ selama 10 hari kemudian diterminasi pada hari ke-14. Kelompok V diberikan asam asetat 5\% 0,5 ml selama 3 hari kemudian tidak diberikan perlakuan selama 10 hari dan diterminasi pada hari ke-14.

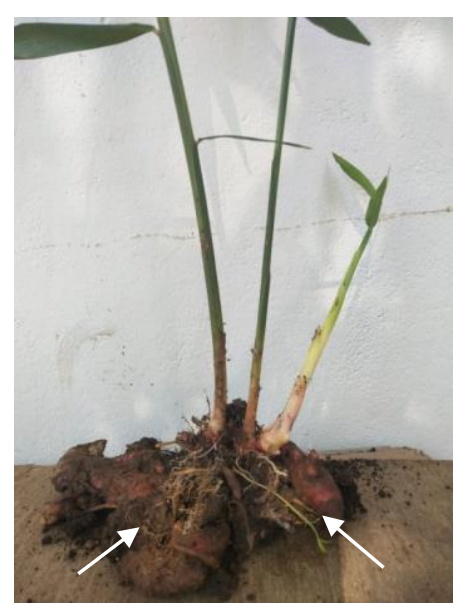

Gambar 1. Jahe merah (Zingiber officinale var. rubrum) yang berasal dari daerah Tomohon, Sulawesi Utara

\section{HASIL PENELITIAN}

Hasil penelitian memperlihatkan berat lambung tikus Wistar yang bervariasi. Konsistensi lambung yang kenyal serta berwarna merah terdapat pada kelompok I (kontrol positif) dan kelompok V yang tidak diberikan jahe; dan warna merah muda pada kelompok perlakuan II, III, dan IV yaitu kelompok perlakuan yang diberikan jahe. 
Gambaran mikroskopik lambung pada kelompok I (kontrol positif) dengan pemberian asam asetat selama 3 hari memperlihatkan permukaan mukosa sebagian tampak erosif, lapisan muskularis tampak edematous, dan kapiler darah melebar (Gambar 2).

Gambaran mikroskopik lambung pada kelompok II yaitu kelompok yang diberikan ekstrak jahe dan asam asetat secara bersamaan memperlihatkan pemukaan mukosa intak dengan sel-sel radang dan pembuluh darah yang melebar (Gambar 3).

Gambaran mikroskopik lambung pada kelompok III yaitu kelompok yang diberikan asam asetat selama 3 hari kemudian dilanjutkan dengan dosis standar ekstrak jahe $0,51 \mathrm{mg}$ selama 10 hari memperlihatkan gambaran permukaan mukosa

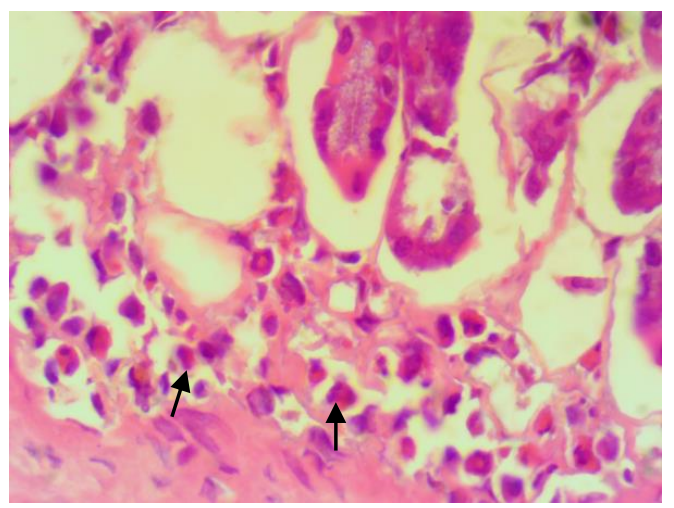

Gambar 2. Gambaran histopatologik lambung tikus Wistar kelompok I (1000x). Ditemukan sel-sel radang pada mukosa bagian bawah (anak panah)

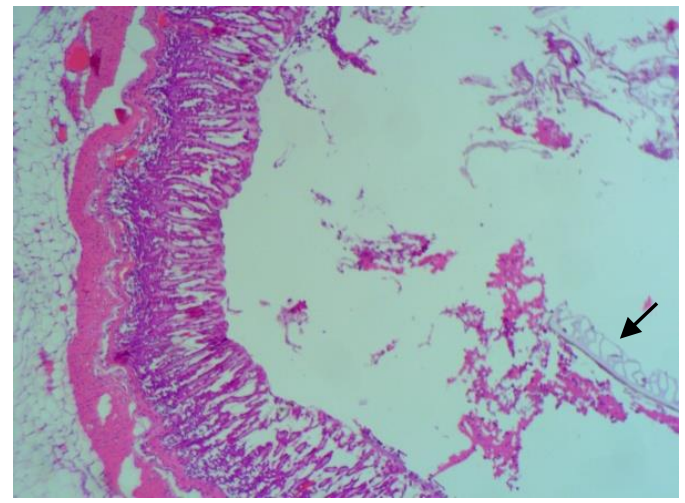

Gambar 4. Gambaran histopatologik lambung tikus Wistar kelompok III (100x). Tampak permukaan mukosa intak dan adanya cacing (anak panah) intak. Lapisan submukosa dan muskularis mukosa diinfiltrasi eosinofil dan PMN disertai gambaran cacing (Gambar 4).

Gambaran mikroskopik lambung pada kelompok IV yaitu kelompok yang diberikan asam asetat $5 \%$ sebanyak $0,5 \mathrm{ml}$ selama 3 hari dilanjutkan pemberian jahe dengan dosis 2 kali per hari selama 10 hari tampak gambaran mukosa permukaan intak, infiltrasi sel-sel radang PMN dan eosinofil, disertai dengan radang supuratif (Gambar 5).

Gambaran mikroskopik lambung pada kelompok $\mathrm{V}$ dengan perlakuan asam asetat $5 \%$ sebanyak $0,5 \mathrm{ml}$ selama 3 hari kemudian tidak diberi perlakuan selama 10 hari tampak gambaran permukaan mukosa yang intak dengan infiltrasi sel radang PMN dan eosinofil yang cukup banyak serta ditemukan adanya cacing (Gambar 6).

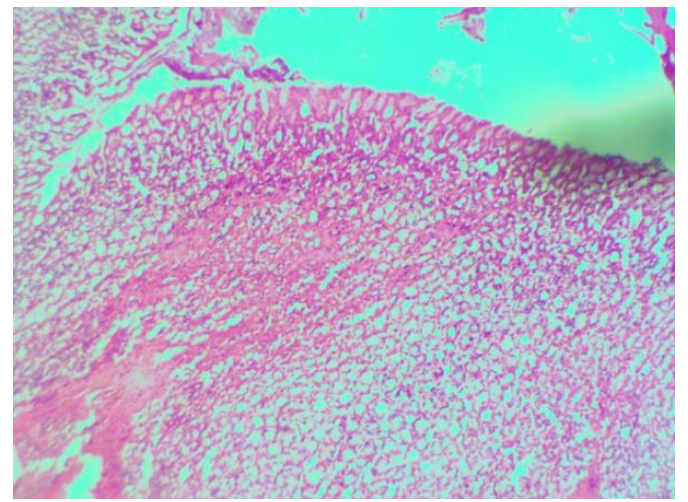

Gambar 3. Gambaran histopatologik lambung tikus Wistar kelompok II (100x). Permukaan mukosa intak dan tidak tampak adanya erosi

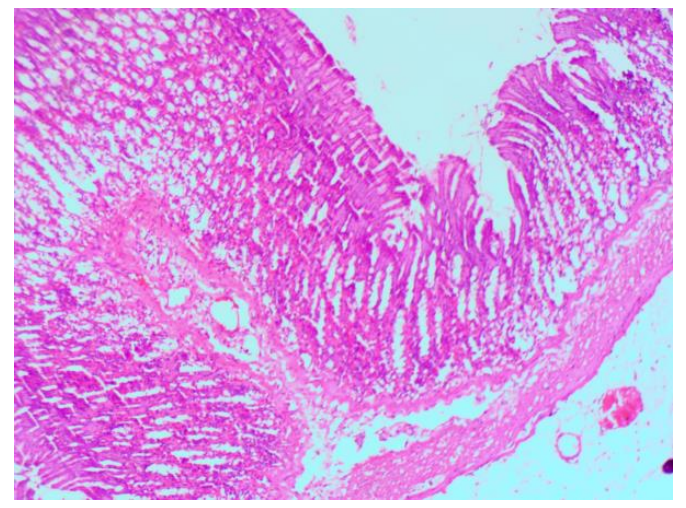

Gambar 5. Gambaran histopatologik lambung tikus Wistar kelompok IV (100x). Tampak dinding lambung dengan permukaan mukosa intak 


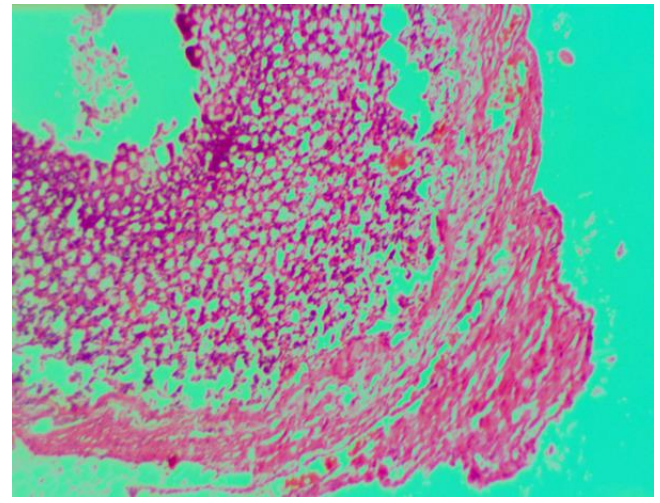

Gambar 6. Gambaran histopatologik lambung tikus wistar kelompok V (100x). Tampak dinding lambung dengan permukaan mukosa intak

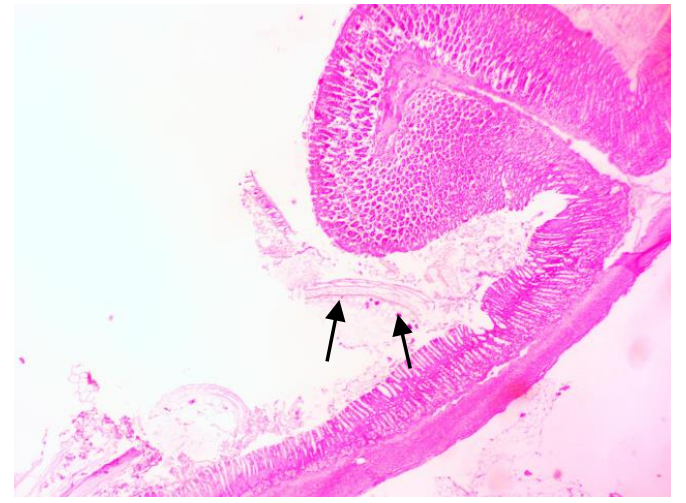

Gambar 7. Gambaran histopatologik lambung tikus wistar kelompok I (40x). Tampak dinding lambung, di atas mukosa terdapat badan cacing (anak panah)

Tabel 1. Gambaran mikroskopik lambung pada perlakuan

\begin{tabular}{|c|c|c|c|c|c|}
\hline Kelompok & $\begin{array}{c}\text { Permukaan } \\
\text { mukosa }\end{array}$ & Sel radang & $\begin{array}{c}\text { Pelebaran } \\
\text { pembuluh darah }\end{array}$ & Parasit & Supuratif \\
\hline I & Erosif & $\begin{array}{l}\text { Eosinofil } \\
\text { PMN }\end{array}$ & Melebar & Tampak & - \\
\hline II & Intak & $\begin{array}{l}\text { Eosinofil, } \\
\text { PMN }\end{array}$ & Melebar & - & - \\
\hline III & Intak & $\begin{array}{l}\text { Eosinofil, } \\
\text { PMN }\end{array}$ & Melebar & Tampak & Tampak \\
\hline IV & Intak & $\begin{array}{l}\text { Eosinofil, } \\
\text { PMN }\end{array}$ & Melebar & Tampak & - \\
\hline V & Intak & $\begin{array}{l}\text { Eosinofil, } \\
\text { PMN }\end{array}$ & Melebar & Tampak & - \\
\hline
\end{tabular}

Pada keseluruh sampel penelitian didapatkan adanya cacing dalam lumen lambung (Gambar 4 dan 7)

\section{BAHASAN}

Pada kelompok kontrol positif dan perlakuan ke-1 sampai ke-4 didapatkan selsel radang (eosinofil dan PMN) dengan jumlah berbeda serta pembuluh darah melebar (Tabel 1). Terdapatnya pembuluh darah yang melebar (vasodilatasi) disebabkan oleh reaksi inflamasi dimana aliran darah meningkat menuju daerah yang mengalami cedera serta peran prostaglandin, nitrik oksida, dan histamin yang merupakan mediator inflamasi dari inflamasi akut. ${ }^{13,15}$

Terdapatnya sel radang eosinofil pada lapisan mukosa lambung, khas terhadap infeksi yang disebabkan oleh parasit. Infeksi yang terjadi pada lambung tikus dapat terkait dengan infestasi nematode khusus- nya nematode pada saluran cerna seperti enterobius vermocularis, trichuris trichiura, ascaris lumbricoides, dan strongyloides stercoralis.

Parasit seperti cacing dapat menyebabkan obstruksi hingga perforasi pada kondisi yang berat. Jalur infeksi nematoda yang hidup dalam saluran cerna dapat melalui oral dan penetrasi melalui kulit. Sebagian besar larva akan bermigrasi melalui pembuluh darah hingga ke saluran cerna namun terdapat beberapa larva memiliki jalur langsung ke saluran cerna. Selanjutnya cacing akan ikut bersama feses dan menjadi matang kemudian dapat menginfeksi kembali pejamu melalui jalur oral dan penetrasi. ${ }^{15,16}$

Pada kelompok kontrol positif, ditemukan adanya gastritis erosif. Asam asetat yang bersifat asam dapat menginhibisi dan menyebabkan hilangnya integritas mekanis- 
me pertahanan mukosa lambung sehingga mengakibatkan erosi pada permukaan lambung. ${ }^{17,18}$

Jahe diketahui sebagai tumbuhan herbal yang mengandung senyawa-senyawa kimia yang dapat bermanfaat dalam berbagai pengobatan penyakit seperti antiinflamasi, gastroprotektif dan antiulserasi. Efek ini disebabkan oleh komponen bioaktif yang terkandung dalam jahe seperti zingerone, zingiberenes, gingerols dan shogaol. Pada penelitian ini, gambaran histopatologik lambung tikus yang diberi jahe memperlihatkan gambaran permukaan mukosa yang intak sedangkan pada kelompok kontrol positif (Kelompok I) terjadi erosi pada permukaan mukosa. Hal ini menunjukkan bahwa pemberian jahe melindungi sel-sel epitel torak lambung.

Berdasarkan penelitian yang telah dilakukan sebelumnya, pemberian asam asetat dengan konsentrasi 5\% selama 3 hari dengan cara injeksi secara makroskopik memberikan gambaran ulkus pada dinding lambung sedangkan jahe secara nyata dapat berperan sebagai antiinflamasi dengan menginhibisi asam arakidonik sehingga menghambat jalur siklooksigenase dan lipooksigenase. ${ }^{5}$ Pada kelompok $\mathrm{V}$ dengan pemberian asam cuka selama 3 hari kemudian tidak diberikan perlakuan selama 10 hari tampak permukaan mukosa intak; hal ini mungkin disebabkan karena terjadi regenerasi sel-sel epitel dalam waktu 3-6 hari. ${ }^{13}$

Gambaran histopatologik lambung pada penelitian ini memperlihatkan gastritis akut pada semua kelompok perlakuan yang diberikan jahe (kelompok II, II, dan IV) dan gambaran gastritis korosif pada kelompok perlakuan tanpa diberi jahe (kelompok I). Selain dapat disebabkan oleh adanya infeksi cacing, dosis asam cuka yang kurang, dosis jahe yang kurang, dan lama pemberian dosis jahe juga turut berperan

\section{SIMPULAN}

Pada tikus Wistar, pemberian jahe setelah lambung diinduksi dengan asam cuka masih menunjukkan adanya gastritis namun tidak terdapat gastritis erosif akut.

\section{Konflik Kepentingan}

Penulis menyatakan tidak terdapat konflik kepentingan dalam studi ini.

\section{DAFTAR PUSTAKA}

1. Mahomoodally MF, Aumeeruddy MZ, Rengasamy KRR, Roshan S, Hammad $\mathrm{S}$, Pandohee J, et al. Ginger and its active compounds in cancer therapy: From folk uses to nano-therapeutic applications. Seminars in Cancer Biology. 2019 Aug 9.

2. Lim TK. Edible Medicinal and NonMedicinal Plants Volume 12. Switzerland: Springer, 2016; p. 469.

3. Hass DJ. In: Feldman M, Friedmad LS, Brandt LJ, editors. Sleisenger and Fordtrans's Gastrointestinal and Liver Disease (10th ed). USA: Springer, 2016; p. 2344-57.

4. Pizzorno JE. Murray MT. Textbook of Natural Medicine (4th ed). St. Louis: Elsevier, 2013; p. 1147-52.

5. Jones MR, Kaye AD. Essence of Anesthesia Practice (4th ed). Philadelphia: Elsevier, 2018; p. 523-4.

6. Sharif MF, Bennett MT. The effect of different methods and solvents on the extraction of polyphenols in ginger (Zingiber officinale). Jurnal Teknologi. 2016;78(11-2):49-54.

7. Zick SM, Djuric Z, Ruffin MT, Litzinger AJ, Normolle DP, Meihua RF, Brenner DE. Pharmacokinetics of 6-Gingerol, 8-Gingerol, 10-Gingerol, and 6Shogaol and conjugate metabolites in healthy human subjects. Cancer Epidemiology Biomarkers \& Prevention. 2008;17(8):1930-6.

8. Grumezescu AM, Holban AM, Therapeutic, Probiotic, and Unconventional Foods. (1st ed). London; Elsevier, 2018; p. 412-3.

9. Karampour NS, Arzi A, Rezaie A, Pashmforoosh M, Kordi F. Gastroprotective effect of zingerone on ethanol-induced gastric ulcers in rats. Medicina. 2019;55(3):64-73.

10. Nabavi SM, Silva AS. Zingiber Officinale (Ginger). Nonvitamin and Nonmineral Nutritional Supplements. London: Elsevier, 2019; p. 1147-53.

11. Pratap SR. Ginger: A potential neutraceutical, an updated review. Int $\mathbf{J}$ Pharmacogn Phytochem Res. 2017; 
9(09):1227-38.

12. Ali BH, Blunden G, Tanira MO, Nemmar A. Some phytochemical, pharmacological and toxicological properties of ginger (Zingiber officinale Roscoe): A review of recent research. Food Chem Toxicol. 2008;46(2):409-420.

13. Kumar V, Abbas A, Fausto N, Aster J. Robbins and Cotran Pathologic Basis of Disease (8th ed). Philadelphia, PA: Elsevier, 2009; p. 43-77, 763-831.

14. Nakao K, Ayako R, Kibayashi K. Evaluatiom of the morphological changes of gastric mucosa induced by a low concentration of acetic acid using a rat model. Forensic and Legal Medicine. 2013;22 (2014):99-106.
15. Lindquist HDA, Cross JH. Helminths. In: Infectious Diseases. Amsterdam: Elsevier, 2017; p. 1763-79.

16. Fritsche TR, Pritt BS. Chapter 63 - Medical Parasitology. In: Henry's Clinical Diagnosis and Management by Laboratory Methods (23rd ed). St. Louis: Elsevier, 2017; p. 1231-83.

17. Kumar V, Abbas AK, Aster JC. Robbins and Cotran Pathologic Basis of Disease (9th ed). Philadelphia, PA: Elsevier, 2012; p. 69-111,760-75.

18. Lash RH, Lauwers GY, Odze RD, Genta RM. Inflammatory Disorders of the Stomach (3rd ed). Philadelphia: Elsevier, 2017; p. 352-401. 